\title{
Effect of Silicon Absorption on Soybean Resistance to Phakopsora pachyrhizi in Different Cultivars
}

Geneviève Arsenault-Labrecque, Département de Phytologie, Centre de Recherche en Horticulture, Université Laval, Québec, Canada G1V 0A6; James G. Menzies, Agriculture and Agri-Food Canada, 195 Dafoe Road, Winnipeg, MB, Canada R3T 2M9; and Richard R. Bélanger, Département de Phytologie, Centre de Recherche en Horticulture, Université Laval, Québec, Canada G1V 0A6

\begin{abstract}
Arsenault-Labrecque, G., Menzies, J. G., and Bélanger, R. R. 2012. Effect of silicon absorption on soybean resistance to Phakopsora pachyrhizi in different cultivars. Plant Dis. 96:37-42.

Silicon $(\mathrm{Si})$ is recognized for its prophylactic role in alleviating diseases when absorbed by plants and has been proposed as a possible solution against soybean rust, caused by Phakopsora pachyrhizi. However, little is known about its potential effects on soybean (Glycine $\max$ ) because the plant's ability to absorb $\mathrm{Si}$ is poorly defined. In this work, our objectives were to evaluate and quantify the absorption of $\mathrm{Si}$ in leaves of different soybean cultivars and to determine if such absorption was able to enhance resistance to soybean rust. In a first set of experiments with $\mathrm{cv}$. Williams 82, hydroponic plants were supplied or not with $\mathrm{Si}$ and inoculated with urediniospores of $P$. pachyrhizi. Chemical analyses revealed no significant differences in the plants' $\mathrm{Si}$

content regardless of the treatment, which translated into no effect on rust incidence. However, in a second set of experiments with different cultivars, plants of Korean cultivar Hikmok sorip absorbed nearly four times more Si than those of Williams 82. At the same time, plants from this cultivar exhibited a near absence of disease symptoms when supplied with Si. This resistance appeared to be the result of hypersensitive (HR) reactions that were triggered when plants were fed with $\mathrm{Si}$. These results support the concept that a plant's innate ability to absorb $\mathrm{Si}$ will dictate the benefits conferred by a treatment with $\mathrm{Si}$ and provide evidence that $\mathrm{Si}$ can protect soybean plants against soybean rust through mediated resistance.
\end{abstract}

Asian soybean rust, caused by Phakopsora pachyrhizi Syd. \& P. Syd, was initially discovered and identified in Asia in 1902 (16). In 2001, the first occurrence of the disease was reported in Paraguay (12), and since then, severe yield losses have been recorded in South America, where soybean (Glycine max) is the largest crop by planting area $(22,37)$. Soybean rust was first reported in the United States in 2004 and since then has been reported in 20 U.S. states (31), and its spread has progressed northward such that urediniospores were reported in Ontario, Canada in 2007 (34). Currently, repeated fungicide treatments are applied to control the disease, generating important economic losses and potential environmental damage. As commercial cultivars resistant to P. pachyrhizi are not yet available (14), research efforts are needed to develop alternative methods of combating this pathogen.

The application of silicon ( $\mathrm{Si}$ ) has been associated with many benefits to agricultural crops, namely as a preventive measure against a number of fungal diseases (8). The presence of amorphous silica $\left(\mathrm{SiO}_{2} \cdot n \mathrm{H}_{2} \mathrm{O}\right)$ or soluble $\mathrm{Si}$ in plant shoots has been shown to enhance resistance to Sphaerotheca fuliginea and $P y$ thium sp. in cucumber $(3,9,23)$, Blumeria graminis f. sp. tritici in wheat (1,27), and Magnaporthe grisea in rice (29) in numerous studies. For reasons still debated, it appears that $\mathrm{Si}$ is particularly effective against biotrophic fungi (10). Given this evidence and the limited options to control soybean rust, it stands to reason that investigation of the potential of $\mathrm{Si}$ as a prophylactic treatment against other biotrophic pathogens such as fungi-causing rust diseases is warranted. In a previous attempt, foliar applications of $\mathrm{Si}$ were reported to reduce the intensity of soybean rust (28), but this work could not correlate the efficacy with $\mathrm{Si}$ absorption in soybean, a key component in reproducible and durable control. In a

Corresponding author: R. R. Bélanger,

E-mail: richard.belanger@fsaa.ulaval.ca

Accepted for publication 16 August 2011.

http://dx.doi.org/10.1094/PDIS-05-11-0376

(C) 2012 The American Phytopathological Society more recent study, Lemes et al. (21) also reported encouraging results with $\mathrm{Si}$ and soybean rust. As previous work would suggest, they had better success with soil amendments than with foliar applications, showing that $\mathrm{Si}$ concentration only increased in plants fed $\mathrm{Si}$ through the roots. The authors could not explain how $\mathrm{Si}$ protected the soybean plants or why the two cultivars tested absorbed Si differently and recommended further research toward resolving these issues.

It is well known that plants will absorb $\mathrm{Si}$ to varying degrees $(7,17,19,25)$ and there is a direct correlation between their ability to absorb this element and the benefits they draw from it. Little is known about these benefits for soybean because this plant's ability to absorb $\mathrm{Si}$ is poorly understood. Over the past decades, some studies have tried to establish the Si uptake capacity of soybean, showing that it will accumulate $\mathrm{Si}$ in its shoots in the presence of soluble $\mathrm{Si}$ in the soil solution $(6,17,35)$. However, techniques available today to measure the silicon content of a plant, such as dosage by inductively coupled-plasma optical emission spectrometry (ICPOES), are extremely precise and reliable (11). Considering the importance of the soybean- $P$. pachyrhizi interaction, we were interested in establishing the extent to which soybean was able to absorb $\mathrm{Si}$ and if $\mathrm{Si}$ could have a preventive effect against soybean rust.

The objectives of the present study were: (i) to evaluate and quantify by ICP-OES and X-ray microanalysis the absorption of $\mathrm{Si}$ in leaves of different soybean cultivars, and (ii) to evaluate if the absorption of Si by different cultivars varied in their resistance to soybean rust.

\section{Materials and Methods}

Plant material and growth conditions in hydroponics. The soybean cultivar Williams 82 was used as a highly susceptible control (30). Also used were the cultivars Hikmok sorip (Korea), Majesta (Canada), and Cristalina (Brazil). Seeds were germinated in plastic petri dishes $(150 \times 15 \mathrm{~mm}$; Fisher Scientific) containing filter paper wetted with sterile distilled water. After 3 days, seedlings were transferred to rockwool in 9-cm pots (Hydroculture Dionne) at a rate of two seeds per pot. The plants were grown in a greenhouse maintained at $25 / 20^{\circ} \mathrm{C}$ with a relative humidity of $65 \%$ and a photoperiod of $14 \mathrm{~h}$. 
Hydroponic systems were used to control Si dosage and mitigate external Si contamination. Roots were immersed in Hoagland solution for $15 \mathrm{~min}$ every $45 \mathrm{~min}$. The final concentration of each trace mineral in the basal Si-free solution was (mg/liter): $\mathrm{KNO}_{3}$ (101), $\mathrm{KCl}$ (221), $\mathrm{CaCl}_{2}$ (235), $\mathrm{K}_{2} \mathrm{HPO}_{4}$ (17), $\mathrm{MgSO}_{4} \cdot 7 \mathrm{H}_{2} \mathrm{O}$ (250), $\mathrm{MgCl}_{2} \cdot 6 \mathrm{H}_{2} \mathrm{O}$ (145), $\mathrm{H}_{3} \mathrm{BO}_{3}$ (0.28), $\mathrm{MnCl}_{2} \cdot 4 \mathrm{H}_{2} \mathrm{O}$ (0.4), $\mathrm{CuSO}_{4} \cdot 5 \mathrm{H}_{2} \mathrm{O}(0.2), \mathrm{ZnSO}_{4} \cdot 7 \mathrm{H}_{2} \mathrm{O}(0.2), \mathrm{Na}_{2} \mathrm{MoO}_{4} \cdot 2 \mathrm{H}_{2} \mathrm{O}(0.15)$, $\mathrm{CoSO}_{4} \cdot 7 \mathrm{H}_{2} \mathrm{O}(0.05)$, Fe as Fe-EDTA (40), all pH 6.2. Buffering capacity was provided by adding $1.0 \mathrm{mM}$ MES (pH 6.2).

Soluble Si was fed to the plants by amending the Hoagland solution with (i) no silicon (control), (ii) $0.4 \mathrm{mM}$, or (iii) $1.7 \mathrm{mM} \mathrm{Si}$ in the form of potassium silicate (Kasil \#6, 23,6\% $\mathrm{SiO}_{2}$, National Silicates). Potassium levels were adjusted in the standard solution to compensate for the input of $\mathrm{K}$ from the Kasil \#6. Treatment of the seedlings with the different solutions began 2 weeks after seedling emergence (day 14). Solutions were replaced every week.

Experiments with $c v$. Williams 82. Repeated experiments $(r=2)$ were initially conducted with plants of Williams 82 . The two treatments (control and $0.4 \mathrm{mM} \mathrm{Si}$ ) contained six replications (one plant each) that were arranged in two completely randomized blocks (three replications per block) $(n=24)$.

Experiments with different cultivars. The second series of experiments consisted of two treatments (control and $1.7 \mathrm{mM} \mathrm{Si}$ ) and four soybean cultivars (Cristalina, Hikmok sorip, Majesta, and
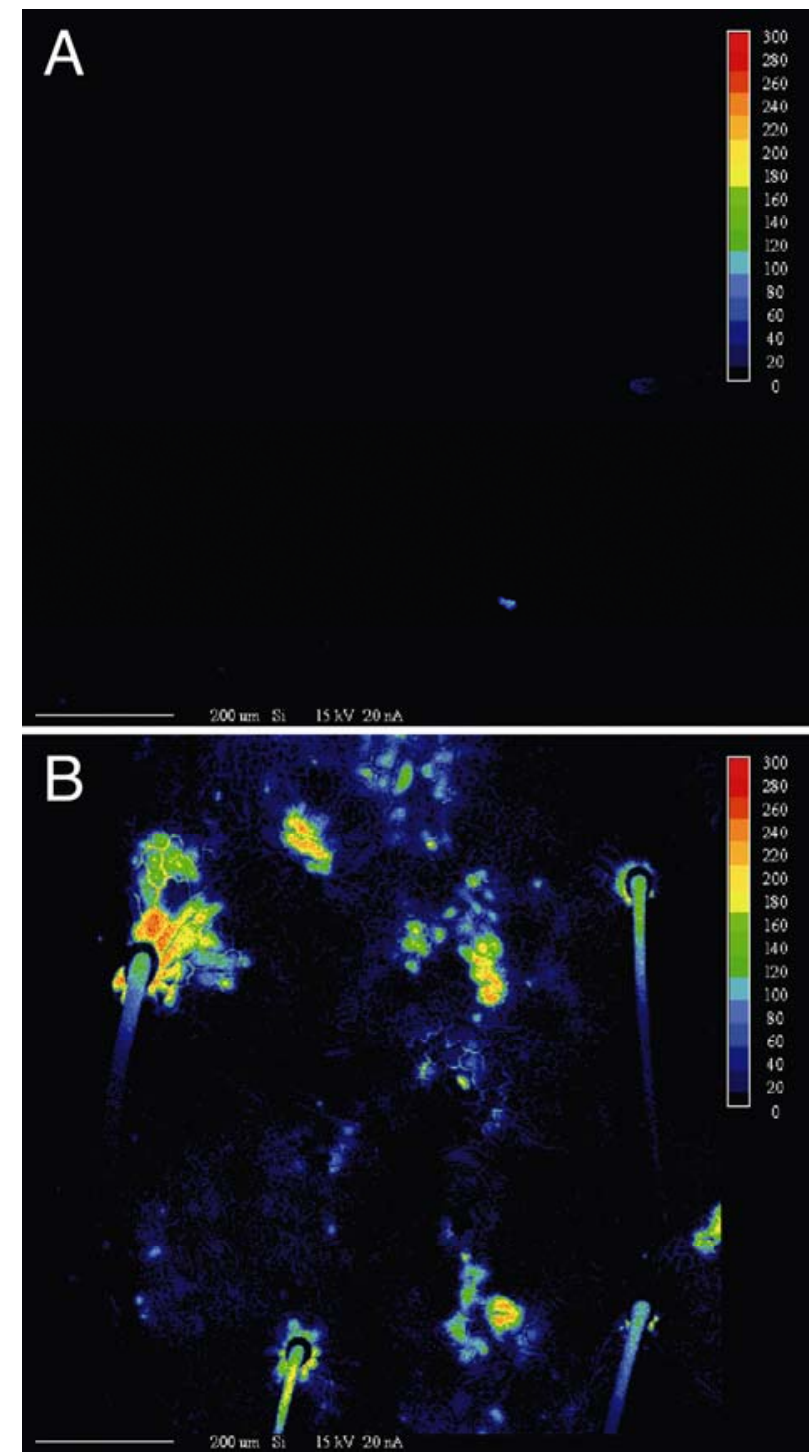

Fig. 1. X-ray microanalysis mapping images from soybean leaves (cv. Williams 82) treated with A, control and B, $0.4 \mathrm{mM}$ silicon (Si). Silicon deposits are indicated by colors. Red represents the highest concentration of $\mathrm{Si}$ and black indicates no $\mathrm{Si}$.
Williams 82) that were arranged in two completely randomized blocks with six replications per cultivar (three replications per block). This experiment was repeated over two seasons: fall and winter $(n=192)$.

Inoculation with $\boldsymbol{P}$. pachyrhizi. The inoculum was prepared with spores obtained from plants grown in a greenhouse previously inoculated with a fungal isolate obtained from the North Florida Research and Education Center (Quincy, FL). One day prior to inoculation, urediniospores stored at $-80^{\circ} \mathrm{C}$ were heat shocked for $5 \mathrm{~min}$ at $40^{\circ} \mathrm{C}$ and hydrated for $16 \mathrm{~h}$ at $100 \%$ relative humidity in a dew chamber. Urediniospores were then suspended in sterile distilled water containing $0.01 \%$ Tween 20 ( vol/vol), and a concentration of $2 \times 10^{4}$ urediniospores per $\mathrm{ml}$ was determined with the aide of a hemacytometer. A volume of $2.5 \mathrm{ml}$ per plant was sprayed onto soybean leaves with an atomizer bottle (Magasin Central d'Énergie). The leaves were covered with 12-lb plastic bags (Bertrand \& Fils Inc.) overnight $(16 \mathrm{~h})$ in the greenhouse at $20^{\circ} \mathrm{C}$ and $90 \%$ relative humidity to maintain leaf wetness. After $16 \mathrm{~h}$, the plastic bags were removed and the inoculated plants were grown at $25 / 20^{\circ} \mathrm{C}$ with a relative humidity of $65 \%$. These experiments were conducted under research permit number P-2009-02974 of the Canadian Food Inspection Agency (CFIA).

X-ray microanalysis of Si deposition. Si deposition within soybean leaves was determined by scanning electron microscopy (SEM) coupled with X-ray microanalysis mapping. For each cultivar, two leaf samples per treatment were collected the third week after commencing silicon treatment (day 35). For each treatment, the middle leaflet of the third trifoliate leaf from the growing tip of the plant was collected. Leaf samples were prepared as described by Guével et al. (15), and SEM analyses were performed using a CAMECA SX-100 Universal EPMT microscope (Cameca Instruments Inc.) operating at a voltage of $15 \mathrm{kV}$ and a current of $20 \mathrm{nA}$.

Silicon content in plant leaves. Inductively coupled plasma optical emission spectrometry (ICP-OES, Jobin-Yvon Horiba JY2000-2) was used to measure silicon content of soybean plants. The third trifoliate leaves from the growing tip of the plant were collected 3 weeks after the beginning of silicon amendment (day 35). For each cultivar, three leaf samples per treatment were obtained. Leaves were freeze-dried, ground to a powder using mortar and pestle, and prepared as described by Côté-Beaulieu et al. (4).

Disease assessment. Observations were made every other day on the first inoculated trifoliate leaves starting 2 days after inoculation. Rust severity was based on the percentage of the leaf area covered by lesions with pustules, using an evaluation scale from 0 to 8 in which a rating of $0=$ no disease, $1=$ up to $2.5 \%$ of leaf area affected, $2=2.5$ to $5 \%, 3=5$ to $10 \%, 4=10$ to $15 \%, 5=15$ to $25 \%, 6=25$ to $35 \%, 7=35$ to $67.5 \%$, and $8=67.5$ to $100 \%$ (Bayer CropScience, 2006). The disease scores for the two plants from each pot were averaged to give one mean score per pot per day. Midpoint values of the disease rating scale were used to plot disease progress curves. In order to compare disease development among treatments, the area under the disease progress curve (AUDPC) was calculated as:

$$
\text { AUDPC }=\sum_{i=1}^{n-1}\left[\left(y_{i}+y_{i+1}\right) \div 2\right]\left(t_{i+1}-t_{i}\right)
$$

where $y_{i}=$ rust severity at the $i$ th observation, $t_{i}=$ time (days), and $n=$ total number of observations (32).

Statistical analysis. Analysis of variance was used to determine significant treatment effects using JMP8 (SAS Institute Inc.). Silicon content in plant leaves and disease assessment (soybean rust development over time and AUDPC) were compared $(P \leq 0.05)$ using Fisher's test.

\section{Results}

Experiments with cv. Williams 82. X-ray microanalysis showed very little $\mathrm{Si}$ deposition in leaves of control soybean plants, thus confirming that the hydroponic system was efficient at minimizing external Si contamination (Fig. 1A). In plants treated with $0.4 \mathrm{mM} \mathrm{Si}, \mathrm{Si}$ deposition was visually more apparent and mostly 
concentrated at the base of trichomes and within cells surrounding them (Fig. 1B).

ICP-OES measurements revealed no significant differences in the overall concentration of $\mathrm{Si}$ between plants treated or not treated with $\mathrm{Si}(1,031$ versus $1,002 \mathrm{ppm})$. On average, the presence of $\mathrm{Si}$ accounted for ca. $0.1 \%$ on a dry weight basis, which would classify soybean Williams 82 as a low accumulator.

For disease assessment, first symptoms for both treatments were observed on soybean leaves 9 days after inoculation with $P$. pachyrhizi. Regardless of the treatments, all plants produced tancolored lesions (designated Tan reactions), indicating a highly susceptible reaction, as opposed to reddish brown lesions (designated $\mathrm{RB}$ reaction), indicating a form of resistance according to the scale used in this study. The disease progressed slowly over the next 2 to 3 weeks and reached a severity plateau between 3 and 3.5 on our rating scale. Area under disease progress curve (AUDPC) showed no significant difference between the treatments. Based on our results, $\mathrm{Si}$ amendments did not appear to influence the severity of rust incidence on Williams 82.

Experiments with different cultivars. X-ray microanalysis of soybean plants grown in a standard nutrient solution without $\mathrm{Si}$ amendments showed no visible Si deposition (results not shown). For the four cultivars treated with $1.7 \mathrm{mM}$, our observations revealed the same pattern of $\mathrm{Si}$ deposition noted in Figure 1 whereby Si was mostly concentrated in and around the trichomes (Fig. 2).
However, differences in $\mathrm{Si}$ accumulation were observed among the cultivars tested, and in particular, Hikmok sorip (Fig. 2A) appeared to have a denser and more regular pattern of $\mathrm{Si}$ presence in leaf cells.

Considering that $\mathrm{Si}$ concentration in planta cannot always be estimated accurately using X-ray microanalysis, shoot content of $\mathrm{Si}$ was quantified by ICP-OES analysis (Fig. 3). ANOVA on the Si concentration data revealed a significant effect of treatment $(F=$ $160.19, P<0.0001)$ for the four cultivars tested. Hikmok sorip accumulated significantly more $\mathrm{Si}$ than all the other cultivars, a result that did concur with the X-ray microanalysis (Fig. 2A to D). Cristalina had an intermediate level of Si accumulation. Williams 82 and Majesta were the lowest accumulators, but Williams 82 did absorb more $\mathrm{Si}$ in this experiment when treated with the $1.7 \mathrm{mM} \mathrm{Si}$ solution. This result was attributed to the higher Si concentration in the treatment solution and to warmer conditions in the greenhouse that favored evapo-transpiration and thus translocation of $\mathrm{Si}$.

Initial assessment of rust severity was done 10 days after inoculation, when the first symptoms were observable on plants (Fig. 4). In control plants, all cultivars produced tan-colored lesions typical of a susceptible reaction. From the onset, Hikmok sorip was the most susceptible and maintained a significantly higher severity of disease throughout the evaluation period (Fig. 4A). For its part, Williams 82 was the least infected and showed considerably less disease symptoms than in the first experiment. AUDPC for each
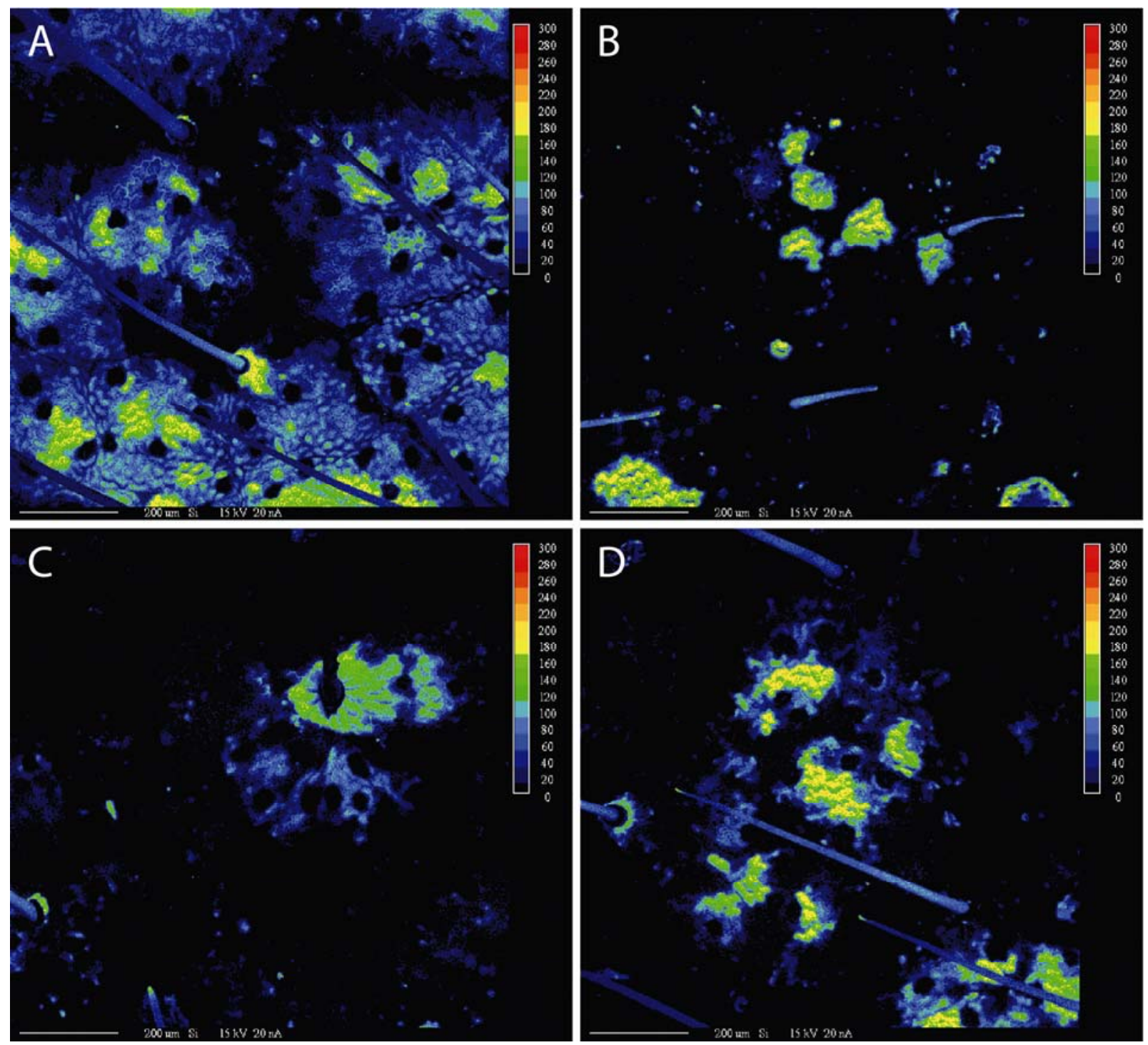

Fig. 2. X-ray microanalysis mapping images from soybean treated with $1.7 \mathrm{mM}$ silicon (Si). Images $\mathbf{A}$ to $\mathbf{D}$ represent different soybean cultivars: $\mathbf{A}$, Hikmok sorip; $\mathbf{B}$, Cristalina; C, Majesta; and D, Williams 82. Si deposits are indicated by colors. Red represents the highest concentration of Si and black indicates no Si. 
season and each cultivar is shown in Table 1. Disease severity was more pronounced in the winter than in the fall season on two of the tested cultivars, as higher condensation always prevails on the leaves of greenhouse plants in the colder winter months. However, the trends were very similar in both seasons in terms of the effect of $\mathrm{Si}$ on disease severity.

When plants were treated with $1.7 \mathrm{mM} \mathrm{Si}$, Hikmok sorip displayed a strong resistance to the disease by producing symptoms typical of a hypersensitive reaction (HR) (Fig. 4B and Fig. 5A). Pustules (uredinia) were not found on any of the inoculated plants (Fig. 5B). In the case of Williams 82, Cristalina, and Majesta, all showed tan-colored lesions with pustules, and their AUDPCs were similar to those observed on plants treated with the $\mathrm{Si}$-free solution.

\section{Discussion}

Despite the urgent need to find alternative methods to fungicides for reducing soybean rust infections, no single strategy has yielded successful control. In this work, the use of silicon amendments has highlighted new and interesting phenomena that could be exploited in efforts to fend off $P$. pachyrhizi.

The application of $\mathrm{Si}$ as a prophylactic measure against plant diseases has proven efficient in a number of plant-pathogen interactions (8). In the case of soybean rust, very few studies have investigated the potential of $\mathrm{Si}$. In most instances, Si was applied to the plant using foliar applications $(5,26,28,36)$. Foliar applications of Si have been found to be much less effective than Si applied as fertilizer because $\mathrm{Si}$ is not absorbed by the leaves and any control effects are probably not related to the intrinsic properties of Si in planta (15). Lemes et al. (21) reported better results against soybean rust with $\mathrm{Si}$-rich soil amendments than with foliar applications, and their data showed no additional accumulation of $\mathrm{Si}$ in plants receiving foliar applications. Under their experimental conditions, plants grown in Si-enriched soil did absorb more $\mathrm{Si}$, but $\mathrm{Si}$ amendments raised soil $\mathrm{pH}$ significantly, which affected the soil-extractable $\mathrm{Ca}$ and $\mathrm{Mg}$ concentrations. In addition, plants from one cultivar appeared to vary in their ability to absorb $\mathrm{Si}$ whether they were grown in the field or in a greenhouse (21). For these reasons, in our experiments, $\mathrm{Si}$ was fed to the plant through a hydroponic solution amended with $\mathrm{Si}$ and buffered at $\mathrm{pH}$ 6.2, in an attempt to determine with precision if soybean cultivars varied in their ability to absorb $\mathrm{Si}$ and if and how $\mathrm{Si}$ could have an effect on rust suppression.

As a first approach, we used X-ray microanalysis images to detect the presence of $\mathrm{Si}$ in leaves of Williams 82. Si deposition within the leaves followed a particular pattern and tended to accumulate in silicaphile cells, as proposed by Blackman (2). Most of

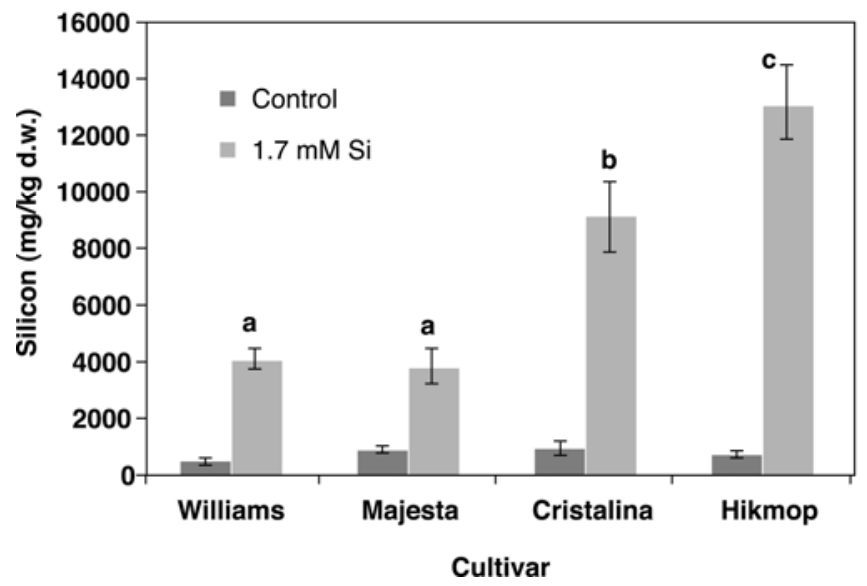

Fig. 3. Silicon (Si) concentration in shoots of soybean plants grown in Hoagland solution (control) or potassium silicate-amended Hoagland solution (1.7 mM Si). Si content was determined by inductively coupled plasma-optical emission spectrometry (ICP-OES). Values with the same letter did not differ significantly at $P \leq$ 0.05 as determined by Fisher's test. these cells are concentrated around the trichomes. This accumulation around the trichomes is coherent with the concept that $\mathrm{Si}$ is translocated to the plant shoots following the evapo-transpiration stream and that water is mostly lost through the stomata and trichomes $(18,33)$.

While X-ray microanalysis images gave a qualitative description of Si deposition, ICP-OES analysis has become the most reliable method to measure Si concentrations in biological material, as the data obtained present less variance than colorimetric methods for instance (11). The results of the ICP-OES analysis revealed that in spite of the apparent differences in Si accumulation indicated by X-ray microanalysis (Fig. 1), the total Si content in plant shoots was not significantly different, whether the plants were treated with $\mathrm{Si}$ or not. This result was somewhat surprising considering that soybean has been described previously as a moderate absorber of $\mathrm{Si}$ (17). On the other hand, because there is a direct link between the ability of a plant to absorb Si and the benefits derived from it, it stands to reason that we found no significant difference in disease severity between controls and plants treated with $\mathrm{Si}$. It is also quite possible that the concentration used, $0.4 \mathrm{mM}$, albeit representative of natural conditions (7), was not sufficient to make a difference in suppressing soybean rust under our test conditions.

The results with Williams 82 raised a concern about the Si uptake capacity of soybean plants. It is recognized that each plant species has its own Si uptake capacity, which would be dictated by the presence of specific Si transporters (24). While no such transporters have been identified yet in soybean, the plant is reported to accumulate moderate levels of Si. Because of the divergence between our results and previous reports, we decided to investigate potential differences in Si absorption among various soybean cultivars, using $1.7 \mathrm{mM} \mathrm{Si}$, which is the maximal solubility of $\mathrm{Si}$ in water (20). Our analyses did reveal intrinsic differences among the
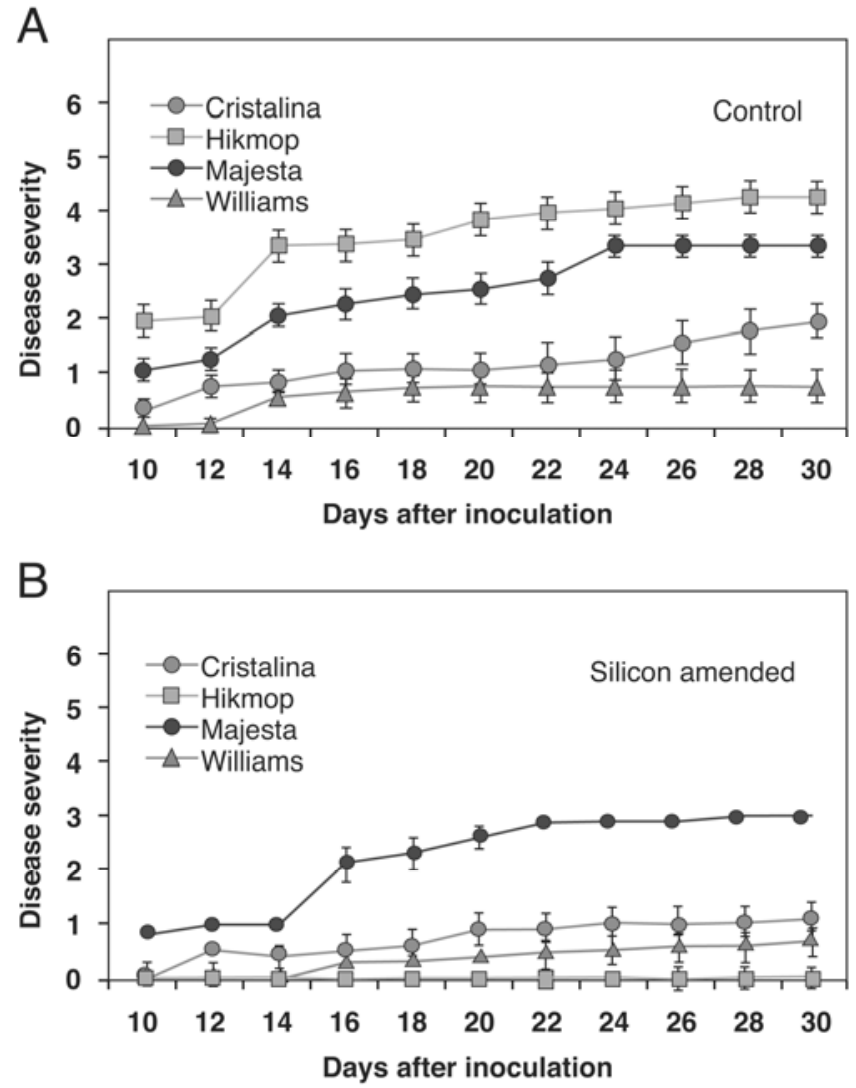

Fig. 4. Soybean rust development over time on soybean plants from different cultivars grown in A, Hoagland solution (control) or B, silicon-amended Hoagland solution. Rust severity was scored on the first trifoliate leaf following the cotyledonal leaves, using an evaluation scale from Bayer CropScience (2006). Score 0 to 8 , based on percent leaf area covered by lesions associated with pustules. 
Table 1. Area under disease progress curve (AUDPC) for soybean rust on different soybean cultivars treated with control or silicon (Si)-amended solutions ${ }^{\mathrm{x}}$

\begin{tabular}{|c|c|c|c|c|}
\hline \multirow[b]{3}{*}{ Cultivars } & \multicolumn{4}{|c|}{ AUDPC $^{y}$} \\
\hline & \multicolumn{2}{|c|}{ Fall } & \multicolumn{2}{|c|}{ Winter } \\
\hline & Control & $1.7 \mathrm{mM} \mathrm{Si}$ & Control & $1.7 \mathrm{mM} \mathrm{Si}$ \\
\hline Williams 82 & $13.05 \mathrm{ab}$ & $7.1 \mathrm{ab}$ & $62.4 \mathrm{~b}$ & $60.17 \mathrm{~b}$ \\
\hline Majesta & $52.67 \mathrm{c}$ & $45.08 \mathrm{c}$ & $68.67 \mathrm{bc}$ & $60.67 \mathrm{~b}$ \\
\hline Cristalina & $19.38 \mathrm{~b}$ & $14.25 \mathrm{~b}$ & $70.17 \mathrm{bc}$ & $81.83 \mathrm{c}$ \\
\hline Hikmok Sorip & $74.79 \mathrm{~d}$ & $0.0 \mathrm{a}$ & $68.2 \mathrm{bc}$ & $0.0 \mathrm{a}$ \\
\hline $\begin{array}{l}\text { Factorial analysis } \\
\text { (Sum of squares) }\end{array}$ & \multicolumn{2}{|c|}{$\begin{array}{l}\text { Silicon: } 11136.99 * * \\
\text { Cultivar: } 18737.28 * *\end{array}$} & \multicolumn{2}{|c|}{$\begin{array}{c}\text { Silicon: } 3110.08 * \\
\text { Cultivar: } 10059.2 * *\end{array}$} \\
\hline
\end{tabular}

x Values with the same letter within each season did not differ significantly at $P \leq 0.05$ as determined by Fisher's test.

y Each value is based on pooled data from repeated experiments $(n=12)$.

$\mathrm{z} * P<0.001, * * P<0.0001$.
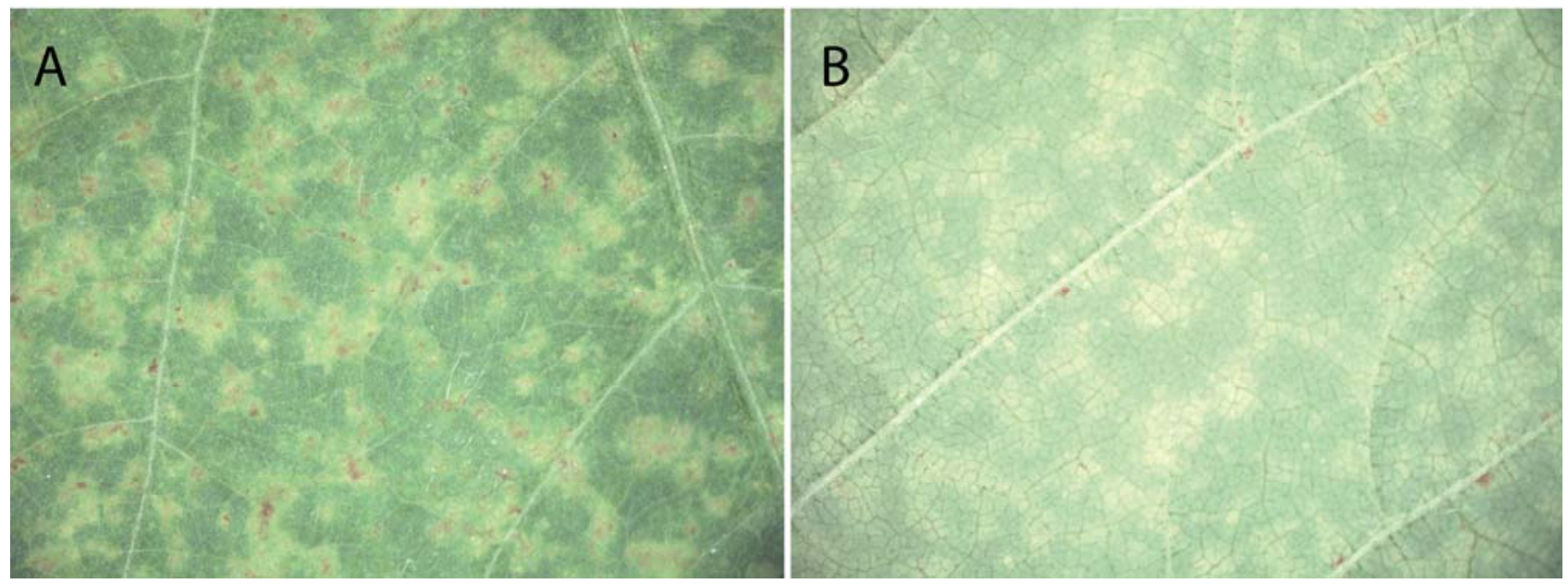

Fig. 5. Hypersensitive reaction caused by Phakopsora pachyrhizi on soybean cultivar Hikmok sorip grown in a $1.7 \mathrm{mM}$ silicon solution. A, Brown specks surrounded by chlorosis, typical of a hypersensitive reaction (HR), on the upper leaf. B, Absence of pustules on the lower leaf.

cultivars tested and highlighted interesting phenomena with one cultivar in particular, Hikmok sorip from Korea. Indeed, unlike the three other cultivars that seemed to accumulate $\mathrm{Si}$ in typical silicaphile cells, Hikmok sorip accumulated Si in a more homogenous pattern over the whole surface of the leaf. ICP-OES analyses confirmed that Hikmok sorip was the highest $\mathrm{Si}$ accumulator among all cultivars tested. It is also noteworthy that plants from Williams 82 did absorb more $\mathrm{Si}$ when fed $1.7 \mathrm{mM}$, a result supporting the notion that $0.4 \mathrm{mM}$ was not high enough in the first set of experiments to make a difference within our experimental conditions. Our results thus show that there exists innate variability within soybean germplasm in terms of $\mathrm{Si}$ absorption. Whether this variability is attributable to the presence or efficacy of Si transporters remains to be elucidated.

The most striking observation in line with this differential Si absorption is arguably the fact that Hikmok sorip displayed the highest resistance to $P$. pachyrhizi when fed with soluble Si. This brings further concrete evidence that $\mathrm{Si}$ accumulation can indeed have a strong prophylactic role against soybean rust in soybean. Perhaps even more convincing is the fact that plants of Hikmok sorip, following $\mathrm{Si}$ treatment and inoculation with urediniospores of $P$. pachyrhizi, displayed symptoms typical of a hypersensitive reaction. This is particularly relevant since $\mathrm{Si}$ feeding has been hypothesized to be associated with induced resistance in recent years and results obtained here tend to confirm, at least in part, this phenomenon. Fawe et al. (10) speculated that $\mathrm{Si}$, in the form of silicic acid, could act as an activator of systemic acquired resistance (SAR) in a manner reminiscent to that of salicylic acid. In additional support to that association, the prophylactic role of $\mathrm{Si}$ has been particularly manifest against biotrophs such as powdery mildews, a class of pathogens known to be affected by defense responses regulated by the salicylic acid-dependent pathway (13). It thus seems logical, as shown here and previously (21), that a biotrophic pathogen such as soybean rust would be affected by $\mathrm{Si}$ nutrition in plants, and yet this is the first report of the HR phenomenon with Si not only for soybean rust but also for any rust pathogen. The implications of our findings could potentially be manifold, not only in providing an additional control approach against soybean rust but also in opening up new possibilities of exploiting the prophylactic properties of Si.

In conclusion, this study provides a thorough description of $\mathrm{Si}$ uptake in soybean plants by relying on the latest techniques of qualitative and quantitative Si analyses; SEM-X-ray microanalysis and ICP-OES. Consequently, our results have highlighted that there exist significant differences in Si absorption within soybean genotypes. These results find their relevance in the observation that Hikmok sorip, the highest $\mathrm{Si}$ accumulator, displayed resistance to soybean rust, through clear manifestation of HR when it was fed with $\mathrm{Si}$ prior to inoculation. This provides further proof that $\mathrm{Si}$ absorption in soybean plants can alleviate infection by soybean rust.

\section{Acknowledgments}

This work was supported by grants from Natural Sciences and Engineering Research Council of Canada (NSERC), and the Canada Research Chairs Program. The authors thank Caroline Labbé and Jonatan Montpetit for technical assistance, Marc Choquette for X-ray microanalysis mapping expertise, Alain Brousseau for ICP-OES analysis, and Dario Narvaèz and Jim Marois from the NFREC for the fungal material (spores of $P$. pachyrhizi).

\section{Literature Cited}

1. Bélanger, R. R., Benhamou, N., and Menzies, J. G. 2003. Cytological evidence of an active role of silicon in wheat resistance to powdery mildew (Blumeria graminis f sp. tritici). Phytopathology 93:402-412.

2. Blackman, E. 1969. Observations on the development of the silica cells of the leaf sheath of wheat (Triticum aestivum). Can. J. Bot. 47:827-838.

3. Chérif, M. A., Asselin, A., and Bélanger, R. R. 1994. Defense responses induced by soluble silicon in cucumber roots infected by Pythium spp. 
Phytopathology 84:236-242.

4. Côté-Beaulieu, C., Chain, F., Menzies, J. G., Kinrade, S. D., and Bélanger, R. R. 2009. Absorption of aqueous inorganic and organic silicon compounds by wheat and their effect on growth and powdery mildew control. Environ. Exp. Bot. 65:155-161.

5. Duarte, H. S. S., Zambolim, L., Rodrigues, F. A., Rios, J. A., and Lope, U. P. 2009. Potassium silicate, acibenzolar-S-methyl and fungicides on the control of soybean rust. Cienc. Rural 39:2271-2277.

6. Ellis, J. R., Watson, D. M. H., Varvel, G. E., and Jawson, M. D. 1995. Methyl-bromide soil fumigation alters plant-element concentrations. Soil Sci. Soc. Am. J. 59:848-852.

7. Epstein, E. 1994. The anomaly of silicon in plant biology. Proc. Natl. Acad. Sci. 91:11-17.

8. Fauteux, F., Rémus-Borel, W., Menzies, J. G., and Bélanger, R. R. 2005. Silicon and plant disease resistance against pathogenic fungi. FEMS Microbiol. Lett. 249:1-6.

9. Fawe, A., Abou-Zaid, M., Menzies, J. G., and Bélanger, R. R. 1998. Silicon-mediated accumulation of flavonoid phytoalexins in cucumber. Phytopathology 88:396-401.

10. Fawe, A., Menzies, J. G., Cherif, M., and Belanger, R. R. 2001. Silicon and disease resistance in dicotyledons. Pages 159-169 in: Silicon in Agriculture, Studies in Plant Science 8. L. E. Datnoff, G. H. Snyder, and G. H. Korndorfer, eds. Elsevier Science, The Netherlands.

11. Frantz, J. M., Locke, J. C., Datnoff, L., Omer, M., Widrig, A., Sturtz, D., Horst, L., and Krause, C. R. 2008. Detection, distribution, and quantification of silicon in floricultural crops utilizing three distinct analytical methods. Commun. Soil Sci. Plant Anal. 39:2734-2751.

12. Freire, M. C. M., de Oliveira, L. O., de Almeida, A. M. R., Schuster, I., Moreira, M. A., Liebenberg, M. M., and Mienie, C. M. S. 2008. Evolutionary history of Phakopsora pachyrhizi (the Asian soybean rust) in Brazil based on nucleotides sequences of the internal transcribed spacer region of the nuclear ribosomal DNA. Genet. Mol. Biol. 31:920-931.

13. Glazebrook, J. 2005. Contrasting mechanisms of defense against biotrophic and necrotrophic pathogens. Annu. Rev. Phytopathol. 43:205-227.

14. Goellner, K., Loehrer, M., Langenbach, C., Conrath, U., Koch, E., and Schaffrath, U. 2010. Phakopsora pachyrhizi, the causal agent of Asian soybean rust. Mol. Plant Pathol. 11:169-177.

15. Guével, M.-H., Menzies, J. G., and Bélanger, R. R. 2007. Effect of root and foliar applications of soluble silicon on powdery mildew control and growth of wheat plants. Eur. J. Plant Pathol. 119:429-436.

16. Hennings, V. P. 1903. A few new japanese Uredinaceae. Hedwigia 42:S107108. (German text.)

17. Hodson, M. J., White, P. J., Mead, A., and Broadley, M. R. 2005. Phylogenetic variation in the silicon composition of plants. Ann. Bot. 96:1027-1046.

18. Johnson, H. B. 1975. Plant pubescence: An ecological perspective. Bot. Rev. 41:233-258.

19. Jones, L. H. P., and Handreck, K. A. 1967. Silica in soils, plants, and animals. Adv. Agron. 19:107-149.

20. Knight, C. T. G., and Kinrade, S. D. 2001. A primer on the aqueous chemistry of silicon. Pages 57-84 in: Silicon in Agriculture, Studies in Plant Science 8. L. E. Datnoff, G. H. Snyder, and G. H. Korndorfer, eds. Elsevier Science, The Netherlands

21. Lemes, E., Mackowiak, C. L., Blount, A., Marois, J. J., Wright, D. L., Coelho, L., and Datnoff, L. E. 2011. Effects of silicon applications on soybean rust development under greenhouse and field conditions. Plant Dis. 95:317-324.
22. Li, X., Esker, P. D., Pan, Z., Dias, A. P., Xue, L., and Yang, X. B. 2010. The uniqueness of the soybean rust pathosystem: An improved understanding of the risk in different regions of the world. Plant Dis. 94:796-806.

23. Liang, Y. C., Sun, W. C., Si, J., and Romheld, V. 2005. Effects of foliar- and root-applied silicon on the enhancement of induced resistance to powdery mildew in Cucumis sativus. Plant Pathol. 54:678-685.

24. Ma, J. F., Tamai, K., Yamaji, N., Mitani, N., Konishi, S., Katsuhara, M., Ishiguro, M., Murata, Y., and Yano, M. 2006. A silicon transporter in rice. Nature 440:88-691.

25. Miyake, Y., and Takahashi, E. 1985. Effect of silicon on the growth of soybean plants in a solution culture. Soil Sci. Plant Nutr. 31:625-636.

26. Pereira, S. C., Rodrigues, F. A., Carré-Missio, V., Oliveira, M. G. A., and Zambolim, L. 2009. Aplicação foliar de silício na resistência da soja à ferrugem e na atividade de enzimas de defesa. Trop. Plant Pathol. 34:164-170.

27. Rémus-Borel, W., Menzies, J. G., and Bélanger, R. R. 2005. Silicon induces antifungal compounds in powdery mildew-infected wheat. Physiol. Mol. Plant Pathol. 66:108-115.

28. Rodrigues, F. A., Duarte, H. S. S., Domiciano, G. P., Souza, C. A., Korndörfer, G. H., and Zamnolim, L. 2009. Foliar application of potassium silicate reduces the intensity of soybean rust. Australas. Plant Pathol. 38:366-372.

29. Rodrigues, F. A., McNally, D. J., Datnoff, L. E., Jones, J. B., Labbé, C., Benhamou, N., Menzies, J. G., and Bélanger, R. R. 2004. Silicon enhances the accumulation of diterpenoid phytoalexins in rice: A potential resistance for blast resistance. Phytopathology 94:177-183.

30. Schmutz, J., Cannon, S. B., Schlueter, J., Ma, J., Mitros, T., Nelson, W., Hyten, D. L., Song, Q., Thelen, J. J., Cheng, J., Xu, D., Hellsten, U., May, G. D., Yu, Y., Sakurai, T., Umezawa, T., Bhattacharyya, M. K., Sandhu, D., Valliyodan, B., Lindquist, E., Peto, M., Grant, D., Shu, S., Goodstein, D., Barry, K., Futrell-Griggs, M., Abernathy, B., Du, J., Tian, Z., Zhu, L., Gill, N., Joshi, T., Libault, M., Sethuraman, A., Zhang, X. C., Shinozaki, K. Nguyen, H. T., Wing, R. A., Cregan, P., Specht, J., Grimwood, J., Rokhsar, D., Stacey, G., Shoemaker, R. C., and Jackson, S. A. 2010. Genome sequence of the palaeopolyploid soybean. Nature 463:178-183.

31. Schneider, R. W., Hollier, C. A., Whitam, H. K., Palm, M. E., McKemy, J. M., Hernandez, J. R., Levy, L., and DeVries-Paterson, R. 2005. First report of soybean rust caused by Phakopsora pachyrhizi in the continental United States. Plant Dis. 89:774.

32. Shanner, G., and Finney, R. E. 1977. The effect of nitrogen fertilization on the expression of slow-mildewing resistance in Knox wheat. Phytopathology 67:1051-1056.

33. Tanton, T. W., and Crowdy, S. H. 1972. Water pathways in higher plants. J. Exp. Bot. 23:619-625.

34. Tenuta, A., Hambleton, S., and Devitt, C. 2008. Soybean rust spores found in Ontario. CropPest Ontario 13:1-2. http://www.omafra.gov.on.ca/english/ crops/field/news/croppest/2008/11cpo08.pdf.

35. Van der Vorm, P. D. J. 1985. Uptake of Si by five plants species, as influenced by variation in Si-supply. Plant Soil 56:153-156.

36. Visser, D. D., Caldwell, P. M., and Laing, M. D. 2008. The effect of potassium silicate on the development of Phakopsora pachyrhizi on soybean. Page 86 in: Silicon in Agriculture Conference South Africa, 4th International Conference. Wild Coast Sun, Port Edward, KwaZulu-Natal, South Africa.

37. Yorinori, J. T., Paiva, W. M., Frederick, R. D., Costamilan, L. M., Bertagnolli, P. F., Hartman, G. E., Godoy, C. V., and Nunes, J., Jr. 2005. Epidemics of soybean rust (Phakopsora pachyrhizi) in Brazil and Paraguay from 2001 to 2003. Plant Dis. 89:675-677. 